This is the accepted manuscript of the following article:

Huang, J., Yan, Y., Remhof, A., Zhang, Y., Rentsch, D., Au, Y. S., ... Züttel, A. (2016). A novel method for the synthesis of solvent-free $\mathrm{Mg}(\mathrm{B} 3 \mathrm{H} 8) 2$. Dalton Transactions, 45(9), 3687-3690.

http://doi.org/10.1039/C5DT04517G

\title{
COMMUNICATION
}

Received 00th January 20xx Accepted 00th January 20xx

\section{A novel method for the synthesis of solvent-free $\mathrm{Mg}\left(\mathrm{B}_{3} \mathrm{H}_{8}\right)_{2}$}

\author{
Jianmei Huang, ${ }^{a, b, c}$ Yigang Yan, ${ }^{c *}$ Arndt Remhof, ${ }^{c}$ Yucheng Zhang, ${ }^{c}$ Daniel Rentsch, ${ }^{c}$ Yuen S. Au, \\ Petra E. de Jongh, ${ }^{d}$ Fermin Cuevas, ${ }^{e}$ Liuzhang Ouyang, ${ }^{a^{*}}$ Min Zhu, ${ }^{a}$ Andreas Züttel ${ }^{b, c}$
}

This communication presents a novel and solvent-free method to synthesise $\mathrm{Mg}\left(\mathrm{B}_{3} \mathrm{H}_{8}\right)_{2}$ via the gas-solid reaction between $\mathrm{B}_{2} \mathrm{H}_{6}$ and $\mathrm{Mg}_{2} \mathrm{NiH}_{4}$, which overcomes the limitations of wet chemical methods requiring solvent removal.

Octahydrotriborate $\left[\mathrm{B}_{3} \mathrm{H}_{8}\right]^{-}$is the third member of the hydroborate series after $\left[\mathrm{BH}_{4}\right]^{-}$and $\left[\mathrm{B}_{2} \mathrm{H}_{7}\right]^{-}$. It has been widely utilised as a precursor in chemical reactions such as the chemical vapour deposition (CVD) of metal-boride (e.g., $\mathrm{MgB}_{2}$ and $\mathrm{CrB}_{2}$ ) thin films, ${ }^{1,2}$ and the synthesis of higher boranes, ${ }^{3,4}$ or carborane cluster compounds. $^{5}$ Owing to their high hydrogen density, octahydrotriborates have also been discussed as hydrogen storage materials (e.g., $\left.\mathrm{NaB}_{3} \mathrm{H}_{8}, \mathrm{NH}_{4} \mathrm{~B}_{3} \mathrm{H}_{8}\right){ }^{6,7}$ Recently, $\left[\mathrm{B}_{3} \mathrm{H}_{8}\right]^{-}$compounds have received particular attention, as they were observed as crucial intermediates in the decomposition of metal borohydrides, for example, $\mathrm{Mg}\left(\mathrm{B}_{3} \mathrm{H}_{8}\right)_{2}$ in the case of $\mathrm{Mg}\left(\mathrm{BH}_{4}\right)_{2}{ }^{8-10}$ However, their roles in hydrogen sorption cycles have not been fully understood and their properties such as stability and reactivity are still unknown, owing to the challenge of synthesising compounds (e.g., $\left.\mathrm{Mg}\left(\mathrm{B}_{3} \mathrm{H}_{8}\right)_{2}\right)$ in a solvent-free state.

The preparation of solvent-free $\mathrm{NaB}_{3} \mathrm{H}_{8}$ has been reported. ${ }^{11-14} \mathrm{~A}$ common synthetic route involves the use of $\mathrm{Na} / \mathrm{Hg}$ amalgam, which reacts either with $\mathrm{B}_{2} \mathrm{H}_{6}$ or THF- $\mathrm{BH}_{3}$ to form $\mathrm{NaB}_{3} \mathrm{H}_{8}$, with $\mathrm{NaBH}_{4}$ as a by-product. ${ }^{11-13}$ By applying diethyl ether, insoluble $\mathrm{NaBH}_{4}$ could be easily separated and $\mathrm{NaB}_{3} \mathrm{H}_{8}(\mathrm{THF})_{x}$ could be obtained when THF. $\mathrm{BH}_{3}$ was used; this complex can be de-solvated after breaking the coordination between THF and $\mathrm{Na}$ by adding $\mathrm{CH}_{2} \mathrm{Cl}_{2}$ followed by heating under a vacuum. Attempts to synthesise $\mathrm{Mg}\left(\mathrm{B}_{3} \mathrm{H}_{8}\right)_{2}$ have included the metathesis reaction of $\mathrm{NaB}_{3} \mathrm{H}_{8}$ and $\mathrm{MgBr}_{2}$ in $\mathrm{Et}_{2} \mathrm{O}$ or $\mathrm{Me}_{2} \mathrm{O}$ as well as the reaction between $\mathrm{Mg} / \mathrm{Hg}$ amalgam and $\mathrm{THF} \cdot \mathrm{BH}_{3} \cdot{ }^{1}{ }^{15}, 16$ Both methods resulted in the formation of complexes such as $\mathrm{Mg}\left(\mathrm{B}_{3} \mathrm{H}_{8}\right)_{2}\left(\mathrm{Et}_{2} \mathrm{O}\right)_{2}, \mathrm{Mg}\left(\mathrm{B}_{3} \mathrm{H}_{8}\right)_{2}\left(\mathrm{Me}_{2} \mathrm{O}\right)_{2}$, or $\mathrm{Mg}\left(\mathrm{B}_{3} \mathrm{H}_{8}\right)_{2}(\mathrm{THF})_{x}$. However, the desolvation of these complexes led to the decomposition of $\mathrm{Mg}\left(\mathrm{B}_{3} \mathrm{H}_{8}\right)_{2}$, owing to the strong coordination of $\mathrm{Mg}$ to the solvents.

Gas-solid reactions involving $B_{2} H_{6}$ have been used to synthesise metal borohydrides and metal dodecaborates. ${ }^{9,}{ }^{17-20} \mathrm{Mg}\left(\mathrm{BH}_{4}\right)_{2}$ was, for example, synthesised by reactive ball-milling $\mathrm{MgH}_{2}$ under $\mathrm{B}_{2} \mathrm{H}_{6}$ at room temperature. ${ }^{17}$ Further exposure of $\mathrm{Mg}\left(\mathrm{BH}_{4}\right)_{2}$ to $\mathrm{B}_{2} \mathrm{H}_{6}$ at elevated temperature led to the formation of $\mathrm{MgB}_{12} \mathrm{H}_{12}$ through a B-H condensation process, in which $\mathrm{Mg}\left(\mathrm{B}_{3} \mathrm{H}_{8}\right)_{2}$ was observed as a reaction intermediate. ${ }^{18}$ The presence of metal particles, such as $\mathrm{Ni}$ particles, was reported to facilitate the splitting of $\mathrm{B}_{2} \mathrm{H}_{6}{ }^{21}$ In a recent study, the reaction of $\mathrm{B}_{2} \mathrm{H}_{6}$ and $\mathrm{MgH}_{2}$ (average particle size $10 \mathrm{~nm}$ ) at room temperature was found to be altered when $\mathrm{Ni}$ nanoparticles were present, whereby higher boranes such as $\mathrm{Mg}\left(\mathrm{B}_{5} \mathrm{H}_{8}\right)_{2}$ were formed instead of $\mathrm{Mg}\left(\mathrm{BH}_{4}\right)_{2}{ }^{20}$

$\mathrm{Mg}_{2} \mathrm{NiH}_{4}$ is an ionic hydride composed of $\mathrm{Mg}^{2+}$ and the complex anion $\left[\mathrm{NiH}_{4}\right]^{4-22}$. In the present study, we found that the reaction between $\mathrm{Mg}_{2} \mathrm{NiH}_{4}$ and $\mathrm{B}_{2} \mathrm{H}_{6}$ readily occurs at room temperature, and the formation of $\mathrm{Mg}\left(\mathrm{B}_{3} \mathrm{H}_{8}\right)_{2}$ is observed according to Eqn. (1). This finding provides a facile approach to the direct synthesis of solvent-free $\mathrm{Mg}\left(\mathrm{B}_{3} \mathrm{H}_{8}\right)_{2}$.

$$
\mathrm{Mg}_{2} \mathrm{NiH}_{4}+6 \mathrm{~B}_{2} \mathrm{H}_{6} \rightarrow 2 \mathrm{Mg}\left(\mathrm{B}_{3} \mathrm{H}_{8}\right)_{2}+\mathrm{Ni}+4 \mathrm{H}_{2}
$$

The starting material, a composite of $\mathrm{Mg}_{2} \mathrm{NiH}_{4}$ and carbon aerogel with mass ratio of 1 to 9 (denoted as $\mathrm{Mg}_{2} \mathrm{NiH}_{4} / \mathrm{C}$ ), was prepared by high-energy ball milling (spex8000) under Argon atmosphere for $2 \mathrm{~h}$. Sequentially, $\mathrm{Mg}_{2} \mathrm{NiH}_{4} / \mathrm{C}$ was directly exposed to $\mathrm{B}_{2} \mathrm{H}_{6}$ at room temperature for 3 days without applying additional ball-milling. Magnesium hydroborates such as $\mathrm{Mg}\left(\mathrm{BH}_{4}\right)_{2}, \mathrm{Mg}\left(\mathrm{B}_{3} \mathrm{H}_{8}\right)_{2}$ and $\mathrm{MgB}_{12} \mathrm{H}_{12}$ have been found to be fully soluble in DMSO, which was thereby used here to extract the newly formed Mg-B-H species for phase identification by solution-state ${ }^{11} \mathrm{~B}$ nuclear magnetic resonance (NMR) measurements. ${ }^{18,23}$ As shown in Fig. 1a, a new resonance at $\delta=-29.3 \mathrm{ppm}$, assigned to the $\left[\mathrm{B}_{3} \mathrm{H}_{8}\right]^{-}$species, was observed in the DMSO- $d_{6}$ solution of the $\mathrm{Mg}_{2} \mathrm{NiH}_{4} / \mathrm{C}$ composite exposed to $\mathrm{B}_{2} \mathrm{H}_{6}{ }^{18}$ It showed a typical nonet splitting with a coupling constant of $33 \mathrm{~Hz}$ (Fig. S2). No additional resonances assignable to side products such as $\mathrm{Mg}\left(\mathrm{BH}_{4}\right)_{2}$ were observed. The $\mathrm{X}$ ray diffraction (XRD) pattern of this sample is shown in Fig. 2a. No obvious decrease in the reflection intensities of the $\mathrm{Mg}_{2} \mathrm{NiH}_{4}$ phase 
was observed after reaction with $\mathrm{B}_{2} \mathrm{H}_{6}$, indicating that the overall reaction yield of $\mathrm{Mg}\left(\mathrm{B}_{3} \mathrm{H}_{8}\right)_{2}$ was limited.
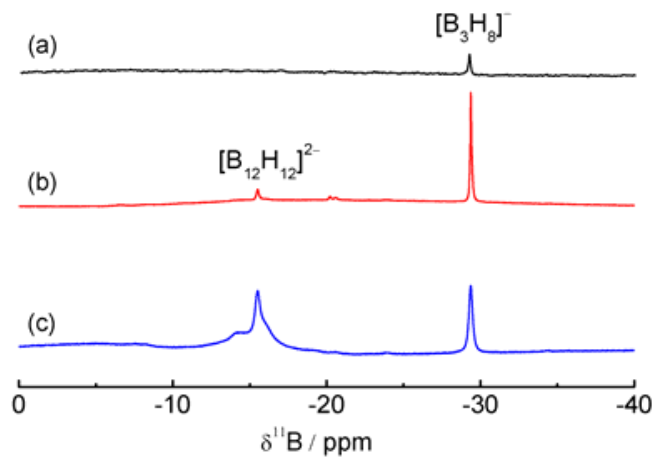

Fig. ${ }^{11} \mathrm{~B}\left\{{ }^{1} \mathrm{H}\right\}$ NMR spectra of DMSO- $d_{6}$ solutions of $\mathrm{Mg}_{2} \mathrm{NiH}_{4} / \mathrm{C}$ composites exposed to $\mathrm{B}_{2} \mathrm{H}_{6}$ at room temperature for (a) 3 days without additional ball-milling or (b) $6 \mathrm{~h}$ and (c) $24 \mathrm{~h}$ with additional ball-milling.

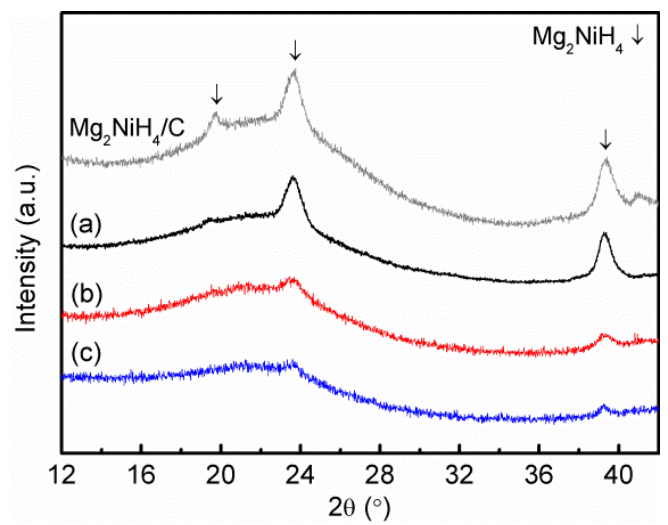

Fig.2 XRD patterns of pristine $\mathrm{Mg}_{2} \mathrm{NiH}_{4} / \mathrm{C}$ and $\mathrm{Mg}_{2} \mathrm{NiH}_{4} / \mathrm{C}$ exposed to $\mathrm{B}_{2} \mathrm{H}_{6}$ at room temperature for (a) 3 days without additional ballmilling or (b) $6 \mathrm{~h}$ and (c) $24 \mathrm{~h}$ with additional ball-milling.

Reaction rate between $\mathrm{Mg}_{2} \mathrm{NiH}_{4} / \mathrm{C}$ and $\mathrm{B}_{2} \mathrm{H}_{6}$ was increased by additional reactive ball-milling (low-energy) at room temperature was applied. ${ }^{17}$ After ball-milling of 6 to $24 \mathrm{~h}$ under $\mathrm{B}_{2} \mathrm{H}_{6}$ atmosphere, the majority of the $\mathrm{Mg}_{2} \mathrm{NiH}_{4}$ phase (Figs. $2 \mathrm{~b}$ and $2 \mathrm{c}$ ) disappeared. Meanwhile, a much stronger $\left[\mathrm{B}_{3} \mathrm{H}_{8}\right]^{-}$resonance was observed by ${ }^{11} \mathrm{~B}$ NMR (Fig. 1b), indicating an improvement in the yield of $\mathrm{Mg}\left(\mathrm{B}_{3} \mathrm{H}_{8}\right)_{2}$ after ball-milling for $6 \mathrm{~h}$. Additionally, a minor resonance at $\delta=-$ $15.3 \mathrm{ppm}$ assigned to $\left[\mathrm{B}_{12} \mathrm{H}_{12}\right]^{2-}$ was observed, which became stronger when ball-milling was performed for $24 \mathrm{~h}$ (Fig. 1c).

The morphologies of $\mathrm{Mg}_{2} \mathrm{NiH}_{4} / \mathrm{C}$ before and after the reaction with $\mathrm{B}_{2} \mathrm{H}_{6}$ were compared by means of transmission electron microscopy (TEM) and scanning TEM (STEM). Pristine $\mathrm{Mg}_{2} \mathrm{NiH}_{4} / \mathrm{C}$ showed aggregation of the $\mathrm{Mg}_{2} \mathrm{NiH}_{4}$ grains (Fig. 3a) with diffraction rings observed in the selected area electron diffraction (SAED) pattern (Fig. 3b), indicating the crystalline nature of the sample. After ball milling of $\mathrm{Mg}_{2} \mathrm{NiH}_{4} / \mathrm{C}$ under $\mathrm{B}_{2} \mathrm{H}_{6}$ for $24 \mathrm{~h}$, the absence of lattice fringes (Fig. $3 \mathrm{C}$ and Fig. S3) and the SAED pattern (the insert of Fig. 3c) indicated only the presence of an amorphous phase. This supports the conversion of crystalline $\mathrm{Mg}_{2} \mathrm{NiH}_{4}$ into an amorphous phase, which is in agreement with the XRD observations (Figs. $2 \mathrm{~b}$ and 2c).
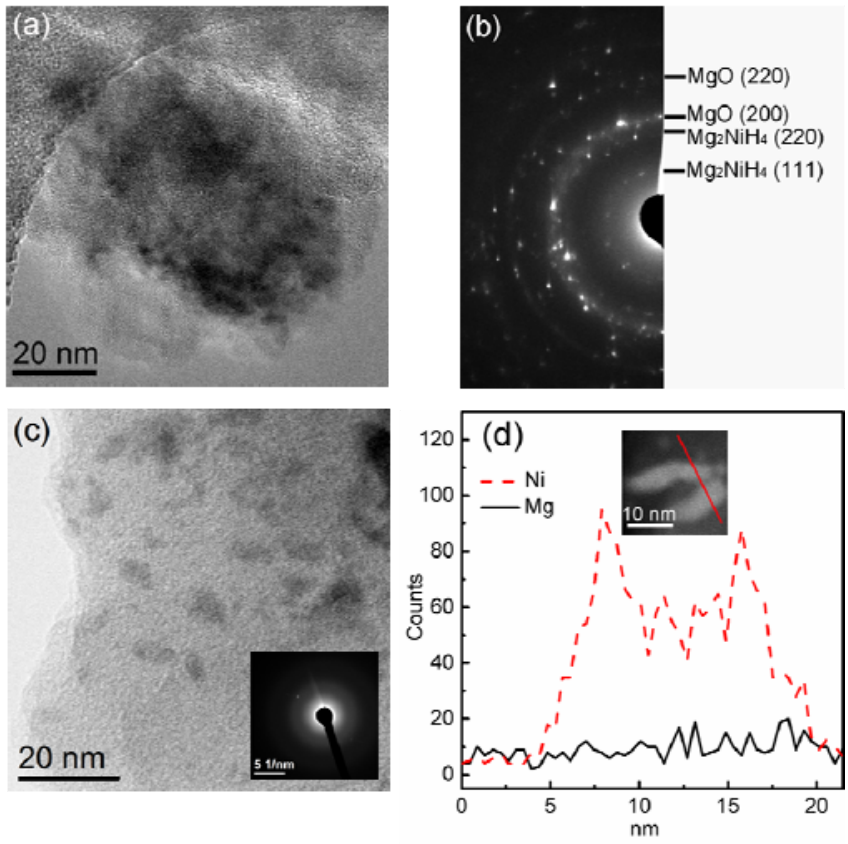

Fig.3 (a) Bright-field TEM image and (b) SAED pattern of $\mathrm{Mg}_{2} \mathrm{NiH}_{4} / \mathrm{C}$. The $\mathrm{MgO}$ phase originated from oxidation of the $\mathrm{Mg}_{2} \mathrm{NiH}_{4}$ during the sample loading process in the air for measurement. (c) Bright-field STEM image and inserted SAED pattern of $\mathrm{Mg}_{2} \mathrm{NiH}_{4} / \mathrm{C}$ ball milled under $\mathrm{B}_{2} \mathrm{H}_{6}$ for $24 \mathrm{~h}$. (d) STEMEDS line profiles of $\mathrm{Mg}$ and $\mathrm{Ni}$ along the red line of inserted STEMHAADF image of selected nanoparticles in (c).

Furthermore, nanoparticles with sizes from 3 to $15 \mathrm{~nm}$ were detected after ball-milling of $\mathrm{Mg}_{2} \mathrm{NiH}_{4} / \mathrm{C}$ under $\mathrm{B}_{2} \mathrm{H}_{6}$ (Fig. $3 \mathrm{C}$ and Fig. S3). To identify the newly-formed nanoparticles observed in Fig. 3c, a selected particle (the insert of Fig. 3d) was measured using an energy-dispersive $\mathrm{X}$-ray spectroscopy (EDS) line scan, following the red line. Here, the bright area refers to $\mathrm{Ni}$-containing particles with higher electron density, while the black area refers to compounds composed of more lightweight elements such as $\mathrm{Mg}, \mathrm{B}, \mathrm{C}$ and $\mathrm{H}$. It was found that $\mathrm{Mg}$ showed a uniform distribution along the entire scanned line, whereas the distribution of $\mathrm{Ni}$ showed a strong dependence on the position (Fig. 3d). The signal of $\mathrm{Ni}$ on the particle (bright area) was much stronger than that away from of the particle (black area). Therefore, the newly formed nanoparticles (Fig. 3c) did contain $\mathrm{Ni}$, but were not $\mathrm{Mg}$-containing compounds (e.g., not $\mathrm{Mg}_{2} \mathrm{Ni}$ ). To determine whether these nanoparticles were metallic $\mathrm{Ni}$ or Ni-B compounds, STEM high angle annular dark field (HAADF) imaging (Figs. S4a and b), EDS mapping (Fig. S4c) and electron energy loss spectroscopy (EELS) (Fig. S4d) measurements were performed. In regions on the selected particle and away from the particle, no obvious difference was observed on both the intensity of the boron signal (Fig. S4c) and the chemical shift of the B K-edge (Fig. S4d). These observations implied the formation of amorphous $\mathrm{Ni}$ nanoparticles. However, it still cannot be ruled out that these amorphous particles are rich in $\mathrm{Ni}$ but contain a small amount of boron atoms forming as $\mathrm{Ni}_{x} \mathrm{~B}^{24}$

We have shown that $\mathrm{Mg}_{2} \mathrm{NiH}_{4}$ readily reacts with $\mathrm{B}_{2} \mathrm{H}_{6}$ at room temperature to form $\mathrm{Mg}\left(\mathrm{B}_{3} \mathrm{H}_{8}\right)_{2}$, according to Eqn. (1). By applying ball-milling, the reaction was faster and the majority of $\mathrm{Mg}_{2} \mathrm{NiH}_{4}$ 
was converted into $\mathrm{Mg}\left(\mathrm{B}_{3} \mathrm{H}_{8}\right)_{2}$ within $6 \mathrm{~h}$. Elongated ball milling resulted in further conversion of $\mathrm{Mg}\left(\mathrm{B}_{3} \mathrm{H}_{8}\right)_{2}$ into $\mathrm{MgB}_{12} \mathrm{H}_{12}$. Ni was

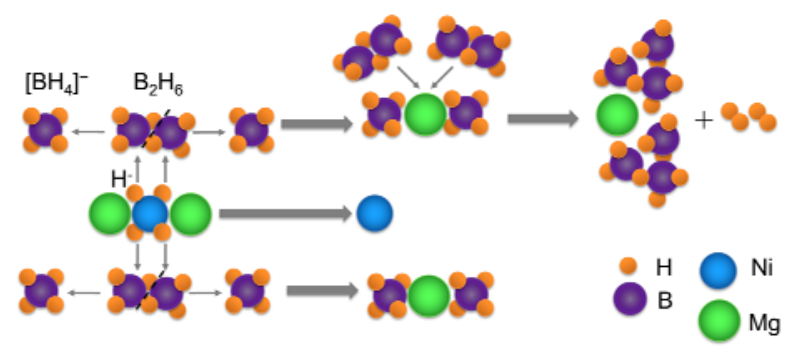

Scheme 1. Proposed mechanism of the reaction between $\mathrm{Mg}_{2} \mathrm{NiH}_{4}$ and $\mathrm{B}_{2} \mathrm{H}_{6}$ to form $\mathrm{Mg}\left(\mathrm{B}_{3} \mathrm{H}_{8}\right)_{2}$ via the intermediate of $\mathrm{Mg}\left(\mathrm{BH}_{4}\right)_{2}$ at room temperature.

considered to be essential for the formation of $\mathrm{Mg}\left(\mathrm{B}_{3} \mathrm{H}_{8}\right)_{2}$ in this study since no $\mathrm{Mg}\left(\mathrm{B}_{3} \mathrm{H}_{8}\right)_{2}$ was formed through the reaction between $\mathrm{MgH}_{2}$ and $\mathrm{B}_{2} \mathrm{H}_{6} \cdot{ }^{17}$ Also, due to the formation of paramagnetic $\mathrm{Ni}$ or $\mathrm{Ni}_{\mathrm{x}} \mathrm{B}$ particles after ball milling, investigation of the yield of $\mathrm{Mg}\left(\mathrm{B}_{3} \mathrm{H}_{8}\right)_{2}$ failed by solid-state ${ }^{11} \mathrm{~B}$ NMR. Thereby quantitative analysis based on solution-state 11B NMR was conducted, using a DMSO-d6 solution of $\mathrm{K}_{2} \mathrm{~B}_{12} \mathrm{H}_{12}(12 \mathrm{mM})$ as the external references (shown in Figure S5). For the sample of $\mathrm{Mg}_{2} \mathrm{NiH}_{4} / \mathrm{C}$ after $6 \mathrm{~h}$ ball milling under $\mathrm{B}_{2} \mathrm{H}_{6}, 10 \mathrm{mg}$ sample was added to $3 \mathrm{~mL}$ of DMSO-d and $a 3.8 \mathrm{mM}$ of $\mathrm{Mg}\left(\mathrm{B}_{3} \mathrm{H}_{8}\right)_{2}$ and $0.27 \mathrm{mM}$ of $\mathrm{MgB}_{12} \mathrm{H}_{12}$ solution were detected by ${ }^{11} \mathrm{~B}$ NMR. The composition of this sample was thus figured out: $12.1 \mathrm{wt} \%, \mathrm{Mg}\left(\mathrm{B}_{3} \mathrm{H}_{8}\right)_{2}, 1.4 \mathrm{wt} \% \mathrm{MgB}_{12} \mathrm{H}_{12}, 3.9 \mathrm{wt} \% \mathrm{Ni}$ (or $\left.\mathrm{Ni}_{x} \mathrm{~B}\right), 6.8 \mathrm{wt} \% \mathrm{Mg}_{2} \mathrm{NiH}_{4}$ residue, and $75.8 \mathrm{wt} \%$ carbon. The conversion ratio of $\mathrm{Mg}_{2} \mathrm{NiH}_{4}$ to $\mathrm{Mg}\left(\mathrm{B}_{3} \mathrm{H}_{8}\right)_{2}$ was $74.5 \%$. Owing to the high vapour pressure, $\mathrm{Mg}\left(\mathrm{B}_{3} \mathrm{H}_{8}\right)_{2}$ could be evaporated from this mixture and collected in a cold trap. The further purification of $\mathrm{Mg}\left(\mathrm{B}_{3} \mathrm{H}_{8}\right)_{2}$ and study its properties are in progress.

The further conversion of $\mathrm{Mg}\left(\mathrm{B}_{3} \mathrm{H}_{8}\right)_{2}$ with $\mathrm{B}_{2} \mathrm{H}_{6}$ results in the formation of $\mathrm{MgB}_{12} \mathrm{H}_{12}$, according to Eqn. (2). This reaction path allows the synthesis of solvent-free $\mathrm{MgB}_{12} \mathrm{H}_{12}$, which was suggested to be a potential solid electrolyte for $\mathrm{Mg}$ battery. ${ }^{25}$

$$
\mathrm{Mg}\left(\mathrm{B}_{3} \mathrm{H}_{8}\right)_{2}+3 \mathrm{~B}_{2} \mathrm{H}_{6} \rightarrow \mathrm{MgB}_{12} \mathrm{H}_{12}+11 \mathrm{H}_{2}
$$

Two reaction paths from $\mathrm{Mg}_{2} \mathrm{NiH}_{4}$ to $\mathrm{Mg}\left(\mathrm{B}_{3} \mathrm{H}_{8}\right)_{2}$ could be considered:

(1) The reaction proceeds via the formation of an intermediate " $\mathrm{Mg}\left(\mathrm{BH}_{4}\right)_{2}$ ". The reaction process is depicted in Scheme 1 . The $\mathrm{Mg}_{2} \mathrm{NiH}_{4}$ complex is composed of $2 \mathrm{Mg}^{2+}$ cations and $\left[\mathrm{NiH}_{4}\right]^{4-}$ anion, in which each $\mathrm{Ni}$ atom is surrounded by four $\mathrm{H}^{-}$in a tetrahedral configuration. ${ }^{22}$ At the first step, $\mathrm{H}^{-}$in $\left[\mathrm{NiH}_{4}\right]^{4-}$ anion may combine with $\mathrm{BH}_{3}$ provided by $\mathrm{B}_{2} \mathrm{H}_{6}$ and form $\left[\mathrm{BH}_{4}\right]^{-}$, resulting in the decomposition of the $\mathrm{Mg}_{2} \mathrm{NiH}_{4}$ and the formation of $\mathrm{Mg}\left(\mathrm{BH}_{4}\right)_{2}$ and $\mathrm{Ni}$ (or existing as $\mathrm{Ni}_{x} \mathrm{~B}$ ).

The adsorption and decomposition of $\mathrm{B}_{2} \mathrm{H}_{6}$ on the $\mathrm{Ni}(100)$ surface have been observed at low temperature. ${ }^{26} \mathrm{Ni}$ and $\mathrm{Ni}_{x} \mathrm{~B}$ were also reported to be catalysts to increase the reaction kinetics for boronbased hydrides during the hydrogen uptake process. ${ }^{20,24,27,28}$ With the presence of the in-situ forming $\mathrm{Ni}$ (or $\mathrm{Ni}_{x} \mathrm{~B}$ ) nanoparticles ( 3 to $15 \mathrm{~nm}$ ), both the splitting of $\mathrm{B}_{2} \mathrm{H}_{6}$ into $\mathrm{BH}_{3}$ unites and the reaction between $\mathrm{Mg}\left(\mathrm{BH}_{4}\right)_{2}$ and $\mathrm{BH}_{3}$ forming $\mathrm{Mg}\left(\mathrm{B}_{3} \mathrm{H}_{8}\right)_{2}$ could be catalysed. The intermediate species " $\mathrm{Mg}\left(\mathrm{BH}_{4}\right)_{2}$ " was not observed in our experiments, possibly owing to its short lifetime.
Note that there was $4 \mathrm{wt} \% \mathrm{Ni}$ residual in the initial $\mathrm{Mg}_{2} \mathrm{NiH}_{4}$ sample, which may trigger the splitting of $\mathrm{B}_{2} \mathrm{H}_{6}$ and result in the reaction between $\mathrm{B}_{2} \mathrm{H}_{6}$ and $\mathrm{Mg}_{2} \mathrm{NiH}_{4}$ forming $\mathrm{Mg}\left(\mathrm{B}_{3} \mathrm{H}_{8}\right)_{2}$ at room temperature without additional ball milling.

(2) The binding energy of $\mathrm{Ni}-\mathrm{H}$ in $\mathrm{Mg}_{2} \mathrm{NiH}_{4}$ is much less than that of $\mathrm{Mg}-\mathrm{H}$ in $\mathrm{MgH}_{2}{ }^{29,30}\left[\mathrm{NiH}_{4}\right]^{4-}$ could donate $\mathrm{H}^{-}$to $\mathrm{B}_{2} \mathrm{H}_{6}$ forming an intermediate, $\left[\mathrm{B}_{2} \mathrm{H}_{7}\right]^{-}$. Once $\left[\mathrm{B}_{2} \mathrm{H}_{7}\right]^{-}$forms, it rapidly react with $\mathrm{B}_{2} \mathrm{H}_{6}$ (or $\mathrm{BH}_{3}$ ) and converts to $\left[\mathrm{B}_{3} \mathrm{H}_{8}\right]^{-}$in presence of $\mathrm{Ni}$ nanoparticles. Similar mechanism has been proposed for the reaction between $\left[\mathrm{BH}_{4}\right]^{-}$and $\mathrm{B}_{2} \mathrm{H}_{6}$ to form $\left[\mathrm{B}_{3} \mathrm{H}_{8}\right]^{-}$, where $\left[\mathrm{BH}_{4}\right]^{-}$may donate one $\mathrm{H}^{-}$to $\mathrm{B}_{2} \mathrm{H}_{6}$ forming $\left[\mathrm{B}_{2} \mathrm{H}_{7}\right]^{-}$as the intermediate. ${ }^{31}$

In summary, we demonstrated a new method to synthesize $\mathrm{Mg}\left(\mathrm{B}_{3} \mathrm{H}_{8}\right)_{2}$ through the reaction between a $\mathrm{Mg}_{2} \mathrm{NiH}_{4} / \mathrm{C}$ composite and $\mathrm{B}_{2} \mathrm{H}_{6}$ gas. The reaction readily occurred at room temperature, which was accelerated by applying ball milling. In-situ formed Ni or $\mathrm{Ni}_{\mathrm{x}} \mathrm{B}$ nanoparticles of 3 to $15 \mathrm{~nm}$ from the dissociation of $\mathrm{Mg}_{2} \mathrm{NiH}_{4}$ was considered to largely promote the formation of $\mathrm{Mg}\left(\mathrm{B}_{3} \mathrm{H}_{8}\right)_{2}$. Furthermore, $\mathrm{MgB}_{12} \mathrm{H}_{12}$ formed by exposure of $\mathrm{Mg}\left(\mathrm{B}_{3} \mathrm{H}_{8}\right)_{2}$ to $\mathrm{B}_{2} \mathrm{H}_{6}$.

This work was supported by the National Natural Science Foundation of China Projects (Nos. 51431001, 51271078 and U120124), by GDUPS (2014), Guangdong Natural Science Foundation (2014A030311004) and by International Science \& Technology Cooperation Program of China (2015DFA51750). Y. Yan and A. Remhof would like to acknowledge the financial support granted by Switzerland through the Swiss Contribution to the enlarged European Union. The NMR hardware was partially granted by the Swiss National Science Foundation (SNFS, grant No. 150638). Part of this work was based on collaboration facilitated by COST Action MP1103 "Nanostructured materials for solid-state hydrogen storage".

\section{Notes and references}

${ }^{a}$ School of Materials Science and Engineering and Key Laboratory of Advanced Energy Storage Materials of Guangdong Province, South China University of Technology, 510641 Guangzhou, China. E-mail: meouyang@scut.edu.ch

${ }^{b}$ Institute of Chemical Sciences and Engineering (ISIC), École polytechnique fédérale de Lausanne (EPFL) Valais/Wallis, Energypolis, 1950 Sion, Switzerland.

'Materials for Renewable Energy, Empa-Swiss Federal Laboratories for Materials Science and Technology, 8600 Dübendorf, Switzerland.E-Mail: yigang.yan@empa.ch

${ }^{d}$ Inorganic Chemistry and Catalysis, Debye Institute for Nanomaterials Science, Utrecht University, Universiteitsweg 99 3584 CG, Utrecht, The Netherlands

${ }^{e}$ CMTR/ICMPE/CNRS UMR 7182, 2-8 rue Henri Dunant, 94320, Thiais Cedex, France

Electronic Supplementary Information (ESI) available: Experimental details, ${ }^{1} \mathrm{H}$-coupled ${ }^{11} \mathrm{~B}$ NMR spectrum of the as synthesised $\left[\mathrm{B}_{3} \mathrm{H}_{8}\right]^{-}$species, and STEM-HAADF image, HRTEM image, $B$ mapping signal and EELS (B) signal of $\mathrm{Mg}_{2} \mathrm{NiH}_{4} / \mathrm{C}$ ball milled under $\mathrm{B}_{2} \mathrm{H}_{6}$ for $24 \mathrm{~h}$. See DOI: 10.1039/x0xx00000x.

1. D. Y. Kim, Y. Yang, J. R. Abelson and G. S. Girolami, Inorg. Chem., 2007, 46, 9060-9066.

2. D. M. Goedde and G. S. Girolami, J. Am. Chem. Soc., 2004, 126, 12230-12231.

3. M. A. Toft, J. B. Leach, F. L. Himpsl and S. G. Shore, Inorg. Chem., 1982, 21, 1952-1957. 
4. H. Beall and D. F. Gaines, Inorg. Chim. Acta., 1999, 289, 110.

5. N. S. Hosmane and R. N. Grimes, Inorg. Chem., 1980, 19, 3482-3487.

6. Z. G. Huang, X. N. Chen, T. Yisgedu, J. C. Zhao and S. G. Shore, Int. J. Hydrogen Energy, 2011, 36, 7038-7042.

7. Z. G. Huang, M. Eagles, S. Porter, E. G. Sorte, B. Billet, R. L. Corey, M. S. Conradi and J. C. Zhao, Dalton T., 2013, 42, 701-708.

8. M. Chong, A. Karkamkar, T. Autrey, S. Orimo, S. Jalisatgi and C. M. Jensen, Chem. Commun., 2011, 47, 1330-1332.

9. Y. Yan, A. Remhof, D. Rentsch, Y.-S. Lee, Y. Whan Cho and A. Zuttel, Chem. Commun., 2013, 49, 5234-5236.

10. Y. Yan, A. Remhof, D. Rentsch and A. Zuttel, Chem. Commun., 2015, 51, 700-702.

11. W. V. Hough, L. J. Edwards and A. D. McElroy, J. Am. Chem Soc., 1958, 80, 1828-1829.

12. T. G. Hill, R. A. Godfroid, J. P. White and S. G. Shore, Inorg. Chem., 1991, 30, 2952-2954.

13. Z. G. Huang, G. King, X. N. Chen, J. Hoy, T. Yisgedu, H. K. Lingam, S. G. Shore, P. M. Woodward and J. C. Zhao, Inorg. Chem., 2010, 49, 8185-8187.

14. A. C. Dunbar, J. A. Macor and G. S. Girolami, Inorg. Chem., 2014, 53, 822-826.

15. Z. Huang, G. King, X. Chen, J. Hoy, T. Yisgedu, H. K. Lingam, S. G. Shore, P. M. Woodward and J.-C. Zhao, Inorg. Chem., 2010, 49, 8185-8187.

16. M. Chong, M. Matsuo, S. Orimo, T. Autrey and C. M. Jensen, Inorg. Chem., 2015, 54, 4120-4125.

17. O. Friedrichs, A. Remhof, A. Borgschulte, F. Buchter, S. I. Orimo and A. Zuttel, Phys. Chem. Chem. Phys., 2010, 12, 10919-10922.

18. A. Remhof, Y. Yan, D. Rentsch, A. Borgschulte, C. M. Jensen and A. Züttel, J. Mater. Chem. A, 2014, 2, 72447249.

19. Y. Yan, Y. S. Au, D. Rentsch, A. Remhof, P. E. de Jongh and A. Zuttel, J. Mater. Chem. A, 2013, 1, 11177-11183.

20. Y. S. Au, Y. Yan, K. P. de Jong, A. Remhof and P. E. de Jongh, J. Phys. Chem. C, 2014, 118, 20832-20839.

21. M. Soderlund, P. Maki-Arvela, K. Eranen, T. Salmi, R. Rahkola and D. Y. Murzin, Catal. Lett., 2005, 105, 191-202. P. V. Jasen, E. A. Gonzalez, G. Brizuela, O. A. Nagel, G. A. Gonzalez and A. Juan, Int. J. Hydrogen Energy, 2007, 32, 4943-4948.

23. Y. G. Yan, A. Remhof, D. Rentsch and A. Zuttel, Chem. Commun., 2015, 51, 700-702.

24. P. Ngene, M. H. Verkuijlen, Q. Zheng, J. Kragten, P. J. M. van Bentum, J. H. Bitter and P. E. de Jongh, Faraday Discuss., 2011, 151, 47-58.

25. T. J. Carter, R. Mohtadi, T. S. Arthur, F. Mizuno, R. Zhang, S. Shirai and J. W. Kampf, Angew. Chem. Int. Ed., 2014, 53, 3173-3177.

26. R. M. Desrosiers, D. W. Greve and A. J. Gellman, Surf. Sci., 1997, 382, 35-48.

27. J. Xu, Y. Li, J. Cao, R. Meng, W. Wang and Z. Chen, Catal. Sci. Technol., 2015, 5, 1821-1828.

28. I. Saldan, S. Hino, T. D. Humphries, O. Zavorotynska, M. Chong, C. M. Jensen, S. Deledda and B. C. Hauback, J. Phys. Chem. C, 2014, 118, 23376-23384.

$29 . \quad J . J$. Reilly and R. H. Wiswall, Inorg. Chem., 1968, 7, 22542256.
30. M. Zhu, Y. Lu, L. Ouyang and H. Wang, Materials, 2013, 6, 4654.

31. D. F. Gaines, R. Schaeffer and F. Tebbe, Inorg. Chem., 1963, 2, 526-528. 